\title{
Review
}

\section{Ausdruck, Mitwelt, Ordnung. Zur Ursprünglichkeit einer Dimension des Politischen im Anschluss an die Philosophie des frühen Heidegger}

Ferdinando G. Menga,

Wilhelm Fink, Paderborn, 2018, +392 pp., ISBN: 978-3-7705-6340-1

Contemporary Political Theory (2020) 19, S183-S187. https://doi.org/10.1057/s41296019-00322-2; Published online 26 April 2019

Is it still possible, after the publication of the Schwarzen Hefte, to engage in political philosophy with Heidegger? More precisely: is there a fracture running through Heidegger's thinking that both promotes and betrays a theory of radical democracy? This question is at the heart of Ausdruck, Mitwelt, Ordnung [Expression, With-World, Order. On the Primordiality of a Political Dimension in Connection with the Philosophy of the Early Heidegger], a dazzling book written by one of Italy's most promising and original young political philosophers, Ferdinando Menga.

I'll first offer a survey of the book's structure, then outline its core insight, namely the 'logic of creative expression', and conclude by discussing the latter's implications for the concepts of representation, power and recognition. Indeed, Menga's book is far more than an inquiry into the vicissitudes of the political in Heideggerian philosophy: it is an original and systematic contribution to what are arguably central concepts of contemporary democratic theory.

Focusing on Heidegger's early Freiburg Seminars (1919-1923), rather than on Being and Time and other later writings, Menga's book addresses this question in three, cumulative steps, which the author summarizes as follows: 'description, continuation, critique' (p. 24). First, Menga shows how Heidegger's reflections on the expressive relation between factical life (faktisches Leben) and world clarifies the symbolic or mediated constitution of experience. In turn, the emergence of a world, organized as the tripartite structure composed of environing world (Umwelt), with-world (Mitwelt) and self-world (Selbstwelt), points to the necessarily political dimension of this expressive relation.

(C) 2019 Springer Nature Limited. 1470-8914 Contemporary Political Theory Vol. 19, S3, S183-S187 
In a second step, Menga takes Heidegger beyond Heidegger, discussing the expressive relation between life and world at work in the representational structure of political community in general, and of democratic politics in particular. Menga reconstructs, to this effect, Arendt's and Castoriadis' theories of radical democracy along the lines of Heidegger's account of expression. On the one hand, expression/ representation accounts for the plurality and contingency of community, which are key features of the theories of radical democracy espoused by those two thinkers. On the other, Menga argues that by rejecting representative democracy to the benefit of direct democracy both Arendt and Castoriadis forfeit the ineradicable contingency and plurality of political community, the very features they had identified as constitutive of a democratic politics. That Heidegger's account of expression exposes Arendt's democratic theory as ultimately antidemocratic in its defense of direct democracy is a remarkable philosophical inversion of positions, inasmuch as Arendt is relentless in exposing the anti-political character of Heidegger's thinking!

But Menga does not rest satisfied with having shown how the Freiburg Seminars anticipate a theory of radical democracy. In a third, critical step, he holds that, in opposition to Heidegger's insights about expression, contingency and plurality, the Freiburg Seminars posit that the most original layer of human experience is an intuitive, non-mediated disclosure of the world in its totality by an isolated and selfsufficient self. Here, precisely, lies the anti-democratic, properly ontological, dimension of Heidegger's thinking, a dimension which would be worked out more fully in his later writings.

What I find particularly compelling about Menga's reading of Heidegger is that this fundamental inconsistency — and not merely ambiguity - in the latter's thinking manifests itself in texts written long before his engagement with Nazism. Why, then, does Heidegger end up betraying the dynamic of expression/ representation and its potential to articulate a theory of radical democracy? Menga's answer is that Heidegger, like Arendt and Castoriadis, shies away from fully embracing contingency and plurality as features of the human relation to the world, and a fortiori of a democratic politics.

Here is where Menga's book is perhaps most powerful as a 'diagnosis' of the political in Modernity, and not simply of the possibilities and limitations of political philosophy in a Heideggerian vein. For this antidemocratic feature ensconced in Heidegger's thinking is also effective in a range of political philosophers who critique the political implications of his thinking. Indeed, from different perspectives and in different ways, Heidegger, Arendt and Castoriadis, like many other modern political philosophers, interpret democratic politics as oriented to overcoming contingency and plurality. What is perhaps most fascinating about the Freiburg Seminars, or so Menga argues, is that they lay bare the conflicting responses that govern political modernity's discovery of contingency and plurality, namely, either to supersede contingency and plurality in 'a drive to 
[attain] the absolute' (p. 366), or to fully embrace them as irreducible and constitutive features of a democratic politics. Menga resolutely endorses the latter, a condition he qualifies as 'tragic' (p. 292): if it is to be democratic, politics is and must remain agonistic.

The common thread running throughout Ausdruck, Mitwelt, Ordnung is what Menga calls the 'logic of creative expression', which Heidegger introduces in the Freiburg seminars with the trenchant formula, 'There is only the possibility of expression' (Heidegger 1993, p. 147). For starters, the 'logic of creative expression' articulates the dynamic and (political) implications of intentionality, the founding insight of phenomenology: something appears as something (to someone). Everything turns on the 'as' of 'something as something'. Linking Heidegger's analysis of expression to the work of Merleau-Ponty and Waldenfels, Menga exploits three of its features throughout his book.

First, the expressive 'as' entails that experience is always indirect, always mediated by meanings, themselves caught up in a web of meanings - a world pregiven and co-presented with each expressive act.

Second, and closely related to the first feature, the expressive 'as' distils a dynamic that eludes both pure realism and pure constructivism. On the one hand, there is not anything that is given of itself such that a meaning 'mirrors' something given prior to its expression. On the other hand, 'the meant' does not simply collapse into the meaning with which it is disclosed: that something appears as something entails that it appears as this-rather than as that. What obtains meaning through expressive acts is always more and other than how it is meant. Herein lies the ineradicably contingent character of experience and, as a corollary, the ineradicably perspectival nature of our relation to the world, which never appears in its totality but rather only as a limited, environing world-an Umwelt.

Third, creative expression deploys a paradoxical temporality that Menga, following Merleau-Ponty and Waldenfels, characterizes as follows: 'something is not simply something, but rather becomes what it is by repeating itself' (p. 49). This originating repetition, or original supplement (Derrida), both re-identifies and differentiates something with respect to itself. Creative expression deploys an iterative self-differentiation that refuses domestication by way of a dialectical sublation of negativity.

Crucially, Menga argues, creative expression holds sway in political representation: 'a collective space does not first exist, after which it is represented; it only exists by representing itself' (p. 297). So conceived, representation explains why sustaining the difference between Welt and Umwelt is central to democratic politics. Asserting the ineradicable contingency of any possible representation of a political community amounts to affirming plurality as the primordial condition of politics and, consequently, relinquishing the illusion of a collective self-grounding in an all-encompassing unity.

(c) 2019 Springer Nature Limited. 1470-8914 Contemporary Political Theory Vol. 19, S3, S183-S187 S185 
Creative expression, in the mode of representation, impinges on a range of conceptual pairs through which modern political philosophy articulates the concept of power. There is, first, the opposition between transitive and intransitive power, i.e. power of some individuals over others (Weber) and power that emerges between us, when we 'act in concert' (Arendt). If transitive power takes the form of a representational act that allows a collective world to emerge, this representational act becomes a manifestation of intransitive power, of the power by which we rule over ourselves, to the extent that its addressees retroactively recognize themselves as members of a community, albeit never fully and never definitively: we represent and recognize ourselves 'as' this.

Contra Arendt, because 'we' are represented as this, rather than as that, power and violence can never be fully separated from each other. Creative expression also highlights the paradoxical nature of the relation between constituent and constituted power, which constitutional theories usually present in oppositional terms: 'the foundational interaction ... must presuppose what it institutes ... to be able to determine itself as its founding moment' (p. 306). Interpreted thus, the paradox of constituent power rules out any primordial presence of a collective to itself, such that political order is always and only a political order-ing.

Claude Lefort was keenly aware of the inevitably gerundial- processualnature of political order, which, he argued, democracy embraces by acknowledging the 'empty place' of power. But, as Menga shows, creative expression/political representation resists assigning power to empty or to occupied places. If an empty place of power, hence a situation of collective indeterminacy, renders unintelligible how a collective could ever be represented, a fully occupied space, hence a fully determinate collective, would render representation nugatory. By contrast, creative expression entails that " $[\mathrm{t}]$ he realm of plural interaction ... reveals itself as the primordial past of the instituted collective structure, yet in such a way that this past, which was never a present, never reaches the threshold of a pure present and of a definitive determination' (p. 306).

A range of questions remain to be formulated and answered, one of which is surely whether and how this book can make sense of political praxis as an emancipatory process, if not as the emancipation of humanity in the singular, then perhaps as human emancipations in the plural. Be this as it may, Ausdruck, Mitwelt, Ordnung offers an exceptionally rich and welcome contribution to the theorization of radical democracy.

\section{Reference}

Heidegger, M. (1993). Grundprobleme der Phänomenologie (Wintersemester 1919/90), Gesammelte Ausgabe (Vol. 58). Frankfurt: Vittorio Klostermann. 
Publisher's Note Springer Nature remains neutral with regard to jurisdictional claims in published maps and institutional affiliations.

Hans Lindahl

Tilburg University, Tilburg 5037 AB, The Netherlands Queen Mary University of London, London E1 4NS, UK

lindahl@uvt.nl 